\title{
Evaluation of diagnostic ratios of medium and serious weathered oils from five different oil sources
}

\author{
HE Shijie $^{1,2,3}$, WANG Chuanyuan²*, LI Yantai ${ }^{4}$, YU Hongjun ${ }^{5}$, HAN Bin $^{5}$ \\ ${ }^{1}$ School of Resources and Environmental Engineering, Ludong University, Yantai 264025, China \\ 2 Yantai Institute of Coastal Zone Research, Chinese Academy of Sciences, Yantai 264003, China \\ ${ }^{3}$ University of Chinese Academy of Sciences, Beijing 100049, China \\ ${ }^{4}$ Institute of Public Administration, Shandong Economic University, Jinan 250014, China \\ ${ }^{5}$ First Institute of Oceanography, State Oceanic Administration, Qingdao 266061, China \\ Received 6 November 2014; accepted 16 April 2015
}

(c) The Chinese Society of Oceanography and Springer-Verlag Berlin Heidelberg 2016

\begin{abstract}
Laboratory experiments were conducted to simulate oil weathering process, a medium to long term weathering process for 210-d, using samples collected from five different oil resources. Based on relative deviation and repeatability limit analysis about indexes of these samples, the results show there had been significant changes in diagnostic ratios among the initial and weathered samples of different oils during this process. Changes of selected $n$-alkane diagnostic ratios of all oil samples displayed more obviously than diagnostic ratios of terpanes, steranes and PAHs in this process. Almost all selected diagnostic ratios of terpanes, steranes and PAHs can be efficiently used in tracking sources of hydrocarbon pollution, differentiating from the $n$-alkane diagnostic ratios. In these efficient diagnostic ratios, only four ratios maintained good stability in the weathering processes and are more suitable because their relative deviation (RSD) are lower than $5 \%$.
\end{abstract}

Key words: identification of spilled oils, medium to long term weathering process, simulation experiment, biomarker ratios

Citation: He Shijie, Wang Chuanyuan, Li Yantai, Yu Hongjun, Han Bin. 2016. Evaluation of diagnostic ratios of medium and serious weathered oils from five different oil sources. Acta Oceanologica Sinica, 35(4): 1-8, doi: 10.1007/s13131-015-0721-9

\section{Introduction}

Although there is evidence that the number of oil spills, for example, has decreased in recent decades, spilled oils still are a significant threat to the marine environment (Burgherr, 2007; Frynas, 2012; King et al., 2015; Teich and Pemberton, 2015). Recent studies show that spilled oils are continually polluting China's sea waters and threatening security of ecological environment surrounding, placing the China's marine environment at risk because the frequency of offshore oil spill accident is increasing (Woolgar, 2008; Wang et al., 2009a; Liu and Zhu, 2014). Therefore, tracing accurately the liable sources of these spill oils, as a primary stage, as well as to understand their fate and behavior and assess their potential long-term impact on the environment are extremely important (Wang and Fingas, 2003; Wang and Stout, 2007).

Crude oils from different oilfields contain source specific compounds and have significantly different chemical characteristics (Peters et al., 1992; Wang et al., 1999). Molecular markers and diagnostic indices including $n$-alkanes, isoprenoid hydrocarbons, polycyclic aromatic hydrocarbons, as well as steroidal terpenes compounds can provide specific information on its chemical composition and be linked to the suspected source (Wang et al., 1994, 1999; Kvenvolden et al., 1995; Stout et al., 2001; Wang et al., 2013) and widely used in oil spill studies (Peters et al., 2005; Wang et al., 2006; Liu et al., 2009; Radović et al., 2014).

While there are many troubles after spilled oils go through a series of weathering processes in the marine environment, and especially after moderate or severe weathering processes which strongly change these oils' inherent characteristics of chemical composition and physical properties (Wang et al., 1997; Kingston, 2002; D'Auria et al., 2009; Samuels et al., 2013). Many studies on biomarker indicators in short term weathering processes were involved (Wang and Fingas, 1995; Zhao et al., 2008; Sun et al., 2009; Lemkau et al., 2010; Radović et al., 2014). In contrast, few studies pay attention to medium and long-term weathering laws through weathering experiments in China. In this article, a simulated weathering experiment is performed on oils collected from different oilfields in 2010. Repeatability limit analysis method also is applied to evaluate results of this experiment which can support in the medium and long-term arbitration on oil related accidents.

The aims of this paper are: (1) to compare the chemical composition and their change modes of different oils, (2) to select useful diagnostic ratios that are more resistant to the weathering process.

\section{Materials and methods}

\subsection{Sample and Experimental design}

Five different crude oil samples were collected from five difFoundation item: The National Natural Science Foundation of China under contract No. 41206089; Project of on-site sediment microbial remediation of public area of central Bohai Sea, North China Sea Branch of State Oceanic Administration under contract No. QDZC20150420002; Program of Science and Technology Service Network Initiative, Chinese Academy of Sciences under contract No. KFJ-EW-STS-127. *Corresponding author, E-mail: cywang@yic.ac.cn 
ferent sources (SL-1, DQ-67-75, DQ-1, LH-7-06 and LH-1) to simulate weathering experiments (Table 1) and SL-1 from S12-13 well of Gudong oilfield, DQ-67-75 and DQ-1 from 67-75 well and 67-27 well of Daqing oilfield, LH-7-06 and LH-1 from 7-06 well and $\mathrm{Ou}-27$ well of Liaohe oilfield, respectively. These oil sources belong to three famous oilfields in China: one from Godong oilfield, two from Daqing oilfield and another two from Liaohe oilfield. The Liaohe oilfield and Gudong oilfield are two oilfields near to Bohai Sea where oil pollution is very serious and oil slicks and oil tar balls are frequently found.

Table 1. Sample information of different oils before weathering process

\begin{tabular}{|c|c|c|c|c|c|c|c|c|c|c|c|c|c|}
\hline $\begin{array}{c}\text { Sample } \\
\text { No. }\end{array}$ & Location & $\begin{array}{l}\text { Well } \\
\text { name }\end{array}$ & Range & $\begin{array}{l}\text { Main } \\
\text { peak }\end{array}$ & $\mathrm{Pr} / \mathrm{Ph}^{1)}$ & $\mathrm{Pr} / n-\mathrm{C}_{17}^{2)}$ & $\begin{array}{c}\mathrm{Ph} / n- \\
\mathrm{C}_{18}{ }^{3}\end{array}$ & $\mathrm{OEP}_{1}^{4)}$ & $\mathrm{OEP}_{2}{ }^{5)}$ & $\begin{array}{c}\text { LMW/H } \\
\text { MW }^{6)}\end{array}$ & $\mathrm{CPI}^{7)}$ & $\begin{array}{c}\mathrm{C}_{18} /\left(\mathrm{C}_{12^{-}}\right. \\
\left.\mathrm{C}_{35}\right)^{8)}\end{array}$ & $\mathrm{WR}^{9)}$ \\
\hline DQ-67-75 & $\begin{array}{l}\text { Daqing } \\
\text { oilfield }\end{array}$ & $67-75$ & $\begin{array}{c}n-\mathrm{C}_{9}-n- \\
\mathrm{C}_{32}\end{array}$ & $n-\mathrm{C}_{21}$ & 1.12 & 0.09 & 0.09 & 1.04 & 1.10 & 2.33 & 1.16 & 0.07 & 0.35 \\
\hline DQ-1 & & $67-27$ & $\begin{array}{c}n-\mathrm{C}_{12}-n- \\
\mathrm{C}_{37}\end{array}$ & $n-\mathrm{C}_{21}$ & 1.24 & 0.21 & 0.17 & 1.04 & 1.05 & 1.78 & 1.06 & 0.06 & 0.81 \\
\hline LH-1 & $\begin{array}{l}\text { Liaohe } \\
\text { oilfield }\end{array}$ & Ou-27 & $\begin{array}{c}n-\mathrm{C}_{12}-n- \\
\mathrm{C}_{35}\end{array}$ & $n-\mathrm{C}_{15}$ & 1.07 & 3.64 & 6.27 & 1.19 & 0.61 & 2.24 & 0.87 & 0.02 & 0.80 \\
\hline LH-7-06 & & 7-06 & $\begin{array}{c}n-\mathrm{C}_{12}-n- \\
\mathrm{C}_{35}\end{array}$ & $n-\mathrm{C}_{25}$ & 0.65 & 6.56 & 15.24 & 0.64 & 1.38 & 2.59 & 1.71 & 0.02 & 1.00 \\
\hline SL-1 & $\begin{array}{l}\text { Gudong } \\
\text { oilfield }\end{array}$ & S12-13 & $\begin{array}{c}n-\mathrm{C}_{12}-n- \\
\mathrm{C}_{38}\end{array}$ & $n-\mathrm{C}_{25}$ & 0.35 & 0.65 & 2.05 & 1.03 & 1.06 & 1.27 & 1.08 & 0.04 & 1.46 \\
\hline
\end{tabular}

Notes: ${ }^{1)} \mathrm{Pr} / \mathrm{Ph}$ : pristine/phytane; ${ }^{2)}$ the ratios of pristane $/ n-\mathrm{C}_{17} ;{ }^{3)}$ the ratios of phytane $/ n-\mathrm{C}_{18} ;{ }^{4)} \mathrm{OEP}_{1}=\left(\mathrm{C}_{17}+6 \times \mathrm{C}_{19}+\mathrm{C}_{21}\right) /\left(4 \times \mathrm{C}_{18}+4 \times \mathrm{C}_{20}\right)$; 5) $\mathrm{OEP}_{2}=\left(\mathrm{C}_{21}+6 \times \mathrm{C}_{23}+\mathrm{C}_{25}\right) /\left(4 \times \mathrm{C}_{10}+4 \times \mathrm{C}_{24}\right)$; 6$)$ the sum of $n-\mathrm{C}_{14}$ to $n-\mathrm{C}_{21}$ alkanes relative to the sum of $n$ - $\mathrm{C}_{22}$ to $n$ - $\mathrm{C}_{34}$ alkanes; ${ }^{7)} 1 / 2\left[\left(\mathrm{C}_{25}+\mathrm{C}_{27}+\mathrm{C}_{29}\right.\right.$ $\left.\left.+\mathrm{C}_{31}+\mathrm{C}_{33}\right) /\left(\mathrm{C}_{24}+\mathrm{C}_{26}+\mathrm{C}_{28}+\mathrm{C}_{30}+\mathrm{C}_{32}\right)+\left(\mathrm{C}_{25}+\mathrm{C}_{27}+\mathrm{C}_{29}+\mathrm{C}_{31}+\mathrm{C}_{33}\right) /\left(\mathrm{C}_{26}+\mathrm{C}_{28}+\mathrm{C}_{30}+\mathrm{C}_{32}+\mathrm{C}_{34}\right)\right]$; 8$)$ the ratio of $n-\mathrm{C}_{18} /$ the sum of $n-\mathrm{C}_{12}$ to $n-\mathrm{C}_{35}$ alkanes; ${ }^{9)}$ the sum of $n-\mathrm{C}_{9}$ to $n-\mathrm{C}_{17}$ alkanes relative to the sum of $n-\mathrm{C}_{18}$ to $n-\mathrm{C}_{34}$ alkanes.

Then all oil samples were collected carefully in $250 \mathrm{~mL}$ widemouth glass jars and transported to the laboratory and stored at $4^{\circ} \mathrm{C}$ in a refrigerator before the experiments. A laboratory-scale facility to simulate weathering condition was designed and built on an open-air platform. The five different crude oils were dropped into five tanks $(\mathrm{L} \times \mathrm{B} \times \mathrm{H}=80 \mathrm{~cm} \times 30 \mathrm{~cm} \times 50 \mathrm{~cm})$ with seawater (taken from the sea near Yantai Port and filtered by the 0.45 $\mu \mathrm{m}$ membrane filter in January, 2010, according to the method of Middaugh et al. (1996) and sand on bottom (about $5 \mathrm{~cm}$ thick) respectively. As the experimental condition becomes increasingly closer to the marine field environment, factors including the physical state of the oil, salinity, $\mathrm{pH}$, dissolved oxygen (DO), temperature and competition with microbial communities will influence the artificial weathering process (Bao et al., 2012), so the bacteria pollution in the experiments did not been followed with interest. In total, 3 aliquots of each oil sample were taken periodically on the 30 th, 150th and 210 th day.

\subsection{Extraction and instrumental analysis}

All samples were extracted using a soxhlet apparatus with dichloromethane (DCM) (>99.9\%, Avantor Performance Materials, Inc., Center Valley, PA) for a minimum of $72 \mathrm{~h}$. At the completion of the extraction procedure, sample extracts were filtered through pre-cleaned anhydrous sodium sulfate and concentrated (unless gross oil contamination was observed) to a final volume of 1-2 $\mathrm{mL}$ using rotary evaporation and nitrogen gas blow-down. An aliquot of $1 \mathrm{~mL}$ of each extract was subjected to analysis. Saturated hydrocarbon fractions were eluted with $n$ hexane, and then analyzed by gas chromatograph-mass spectrometer (GC-MS) (Mello et al., 2012; Di Gregorio et al., 2014; Ramsey et al., 2014; Adhikari et al., 2015).

The analyses were done as soon as possible. The GC/MS analyses were carried out on an Agilent (Santa Clara, CA) $6890 \mathrm{~N}$ GC/5973N mass spectrometer equipped with a HP-5 capillary column $(50 \mathrm{~m} \times 0.32 \mathrm{~mm} \times 0.25 \mu \mathrm{m})$. The GC oven temperature was programmed from 80 to $300^{\circ} \mathrm{C}$ at $4^{\circ} \mathrm{C} / \mathrm{min}$, held during 30 $\mathrm{min}$ at this temperature. Helium was used as a carrier gas. Mass spectrometer conditions were electron ionization at $70 \mathrm{eV}$ with an ion source temperature at $250^{\circ} \mathrm{C}$. The deuterated surrogate standards that were initially spiked into each sample were treated as internal standards, where each surrogate compound was associated with a group of calibrated alkanes. Individual $n$-alkanes were identified based on the retention time of the standards $\left(n \mathrm{C}_{10-40}\right.$, Sigma), and concentrations of each $n$-alkane were calculated based on the standard calibration curve of each corresponding standard compound. Biomarker ratios were calculated using peak areas from the $\mathrm{m} / \mathrm{z} 85, \mathrm{~m} / \mathrm{z} 191$ and m/z 217 chromatograms. For quantitative analysis, the response factor for the surrogate standard was calculated by dividing the surrogate concentration by the respective peak area. On the other hand, individual PAHs were quantified based on the retention time and $\mathrm{m} / \mathrm{z}$ ratio of an authentic PAHs mixed standard (Sigma), and concentrations of each PAHs were calibrated based on the standard calibration curve (Wang et al., 2013).

\section{Results and discussion}

Ratios of oil samples collected from Daqing oilfield (No. DQ-1 and No. DQ-67-75) such as pristane/phytane ( $\mathrm{Pr} / \mathrm{Ph})$, odd to even predominance $\left(\mathrm{OEP}_{1}, \mathrm{OPE}_{2}\right)$, carbon preference index (CPI) are in same range, indicating that these two samples are chemically similar and derived from similar marine-influenced source rocks deposited under oxic conditions. While samples from Liaohe Basin (No. LH-1 and No. LH-7-06) show different characteristic marks suggest their deposited environments are distinct although they were collected from the same region. Ratios of the sample collected from Gudong oilfield (No. SL-1) are in very low values, reflecting that they are derived from typify anoxic, commonly hypersaline environment, almost terrigenous organic matter formed under a strong reducing environment (Duan et al., 2008). And the $n$-alkane CPI values of this sample are slightly higher than 1.0 (Table 1), indicate that the sample is mature (George et al., 2008).

\subsection{Variation of distributions of alkanes, pristane and phytane}

Usually $n$-alkanes weathering degree are positively correlated with molecular mass; the smaller the molecular weight, the more obvious weathering degree in the general (Wang et al., 1995). Hydrocarbons after $n-C_{15}$ are less affected by weathering; 
$n$ - $\mathrm{C}_{20}$ hydrocarbons can be regarded as difficult weathering hydrocarbons. Table 2 lists the measurement results of some indicators and ratios in the weathering simulation process.

As shown in Table 2, it is apparent that there are significant differences in the diagnostic ratios, with respect to the $n$-alkanes, pristane and phytane, in the initial oils and weathered oils. The degraded oils exhibit a substantially higher value of the low and high molecular weight ratios (LMW/HMW) compared to the initial oils. It suggests that the short-chain $n$-alkanes decreases gradually with increasing degree of weathering; medium and high chain $n$-alkanes are relatively stable in some samples, because the extent of loss in mass of the short-chain $n$-alkanes is greater than the other components. LMW/HMW declined rapidly during 30 weathering days and slowly during the 30-210 weathering days, because low $n$-alkanes would get serious loss in the short term of weathering experiments. The results are similar to monitoring results of changes in composition of oil spills, occurred after the first few days of weathering mainly by evaporation and dissolution and only $5 \%$ to $10 \%$ for the loss of heavy or residual oils (Lemkau et al., 2010).

Table 2. Changes of diagnostic ratios of $n$-alkanes in different weathered oils

\begin{tabular}{|c|c|c|c|c|c|c|c|c|c|c|}
\hline & \multicolumn{10}{|c|}{ Sample No. } \\
\hline & \multicolumn{2}{|c|}{ DQ-67-75 } & \multicolumn{2}{|c|}{ DQ-1 } & \multicolumn{2}{|c|}{ LH-1 } & \multicolumn{2}{|c|}{ LH-7-06 } & \multicolumn{2}{|c|}{ SL-1 } \\
\hline & $30 \mathrm{~d}^{1)}$ & $210 \mathrm{~d}$ & $150 \mathrm{~d}$ & $210 \mathrm{~d}$ & $150 \mathrm{~d}$ & $210 \mathrm{~d}$ & $30 \mathrm{~d}$ & $210 \mathrm{~d}$ & $150 \mathrm{~d}$ & $210 \mathrm{~d}$ \\
\hline $\mathrm{Pr} / \mathrm{Ph}$ & 0.89 & 0.78 & 0.98 & 1.26 & 1.05 & 0.83 & 0.67 & 0.41 & 0.27 & 0.25 \\
\hline $\mathrm{Pr} / n-\mathrm{C}_{17}$ & 0.11 & 0.12 & 0.24 & 0.33 & 6.34 & 3.26 & 6.70 & 5.81 & 0.67 & 0.64 \\
\hline $\mathrm{Ph} / n-\mathrm{C}_{18}$ & 0.12 & 0.13 & 0.21 & 0.26 & 5.27 & 4.94 & 15.65 & 26.44 & 2.21 & 2.17 \\
\hline $\mathrm{OEP}_{1}$ & 1.05 & 1.11 & 1.01 & 1.01 & 0.81 & 0.92 & 0.70 & 0.45 & 0.98 & 1.00 \\
\hline $\mathrm{OEP}_{2}$ & 1.10 & 1.13 & 1.03 & 1.04 & 1.38 & 1.31 & 1.24 & 0.92 & 1.10 & 1.06 \\
\hline LMW/HMW & 2.39 & 2.01 & 1.21 & 1.38 & 2.30 & 1.54 & 2.44 & 1.55 & 0.83 & 0.86 \\
\hline CPI & 1.21 & 1.20 & 1.03 & 1.05 & 1.27 & 1.12 & 1.79 & 1.74 & 1.07 & 1.07 \\
\hline $\mathrm{C}_{18} /\left(\mathrm{C}_{12}-\mathrm{C}_{35}\right)$ & 0.09 & 0.10 & 0.06 & 0.06 & 0.03 & 0.03 & 0.02 & 0.01 & 0.03 & 0.04 \\
\hline WR & 0.31 & 0.33 & 1.27 & 1.13 & 0.94 & 1.48 & 0.98 & 1.64 & 2.13 & 1.88 \\
\hline
\end{tabular}

Notes: ${ }^{1)}$ Weathering time (d).

As shown in Fig. 1, it is apparent that there are significant differences in the distribution of these fractions, with respect to biomarker diagnostic parameters (e.g., $\mathrm{Pr} / \mathrm{Ph}, \mathrm{Pr} / n-\mathrm{C}_{17}, \mathrm{Ph} / n-\mathrm{C}_{18}$ $\left.\mathrm{OEP}_{1}, \mathrm{OEP}_{2}, \mathrm{LMW} / \mathrm{HMW}, \mathrm{CPI}, \mathrm{C}_{18} /\left(\mathrm{C}_{12}-\mathrm{C}_{35}\right), \mathrm{WR}\right)$, in the different initial oils and their weathered oils. Two samples collected from Daqing oilfield have the similar changes of biomarker diagnostic parameters. But Two samples (Nos LH-1 and LH-7-06) collected from the same Liaohe basin, derived from different source rocks have very distinct initial values and ratio change modes. $\mathrm{Pr} / n-\mathrm{C}_{17}$ of LH-1 changed a lot, in contrast, that of LH-706 declined more slowly during 30 weathering days. Change ways of the sample coming from Gudong oilfield are more similar to the ways of samples collected from Daqing. This indicted that change modes of diagnostic ratios have no correlation to the oilfield that samples collected from.

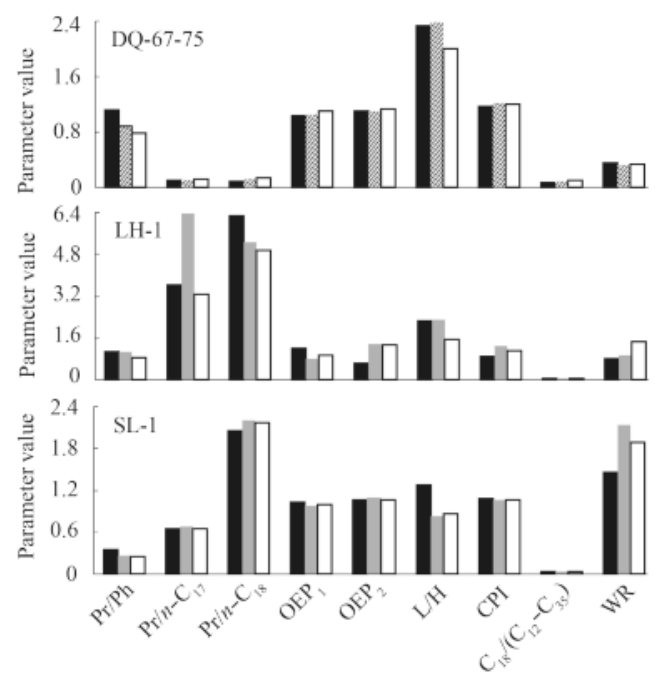

The ratio of pristane to $n$-heptadecane $\left(\mathrm{Pr} / n-\mathrm{C}_{17}\right)$ and phytane to $n$-octadecane $\left(\mathrm{Ph} / n-\mathrm{C}_{18}\right)$ have been widely used as indicators of source rocktypes, depositional environments and organic matter maturation (Peters et al., 1999; Hanson et al., 2000). The increasing of $\mathrm{Pr} / n-\mathrm{C}_{17}$ and $\mathrm{Ph} / n-\mathrm{C}_{18}$ of oils also indicates the relative oil biodegradation degree is increasing (Formolo et al., 2008). Normally, the $n$-alkanes would be degraded significantly prior to alteration of other compound classes, resulting in higher $\mathrm{Pr} / n-\mathrm{C}_{17}$ and $\mathrm{Ph} / n-\mathrm{C}_{18}$ ratios for slightly or moderately biodegraded oils than their non-biodegraded counterparts. From the cross plot of $\mathrm{Pr} / n-\mathrm{C}_{17}$ versus $\mathrm{Ph} / n-\mathrm{C}_{18}$ (Fig. 2 ), it is clear that values of oil samples collected from the same oil fields are near to each other, also with similar weathering modes. For instance, the DQ-1 and DQ-67-75 samples have similar $\mathrm{Pr} / n-\mathrm{C}_{17}$ versus $\mathrm{Ph} / n$ $\mathrm{C}_{18}$ values that are lower than the rest value of other samples.

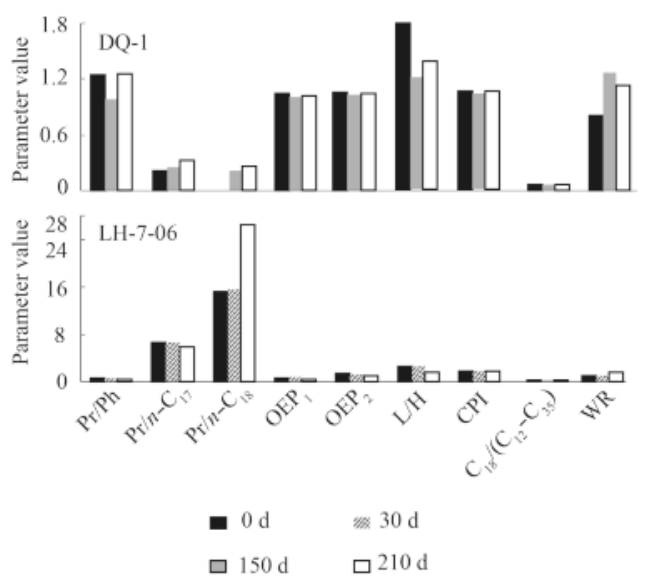

Fig. 1. Changes of ratios of $n$-alkanes in the weathering experiments. 


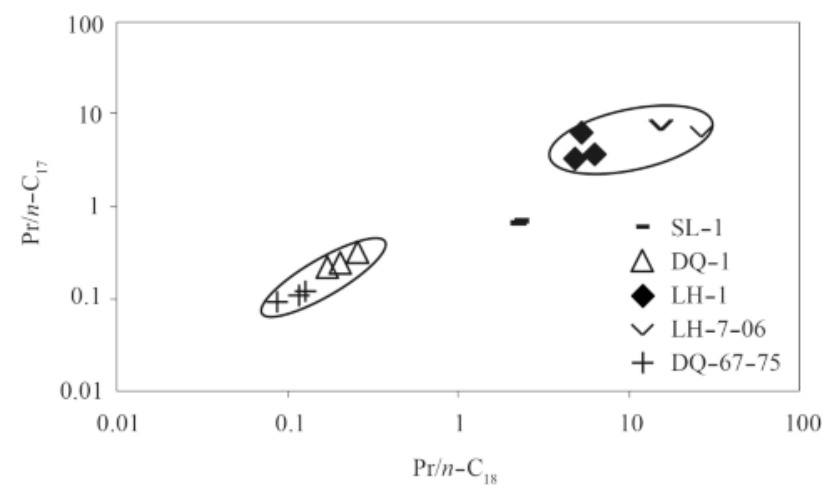

Fig. 2. Pristane $/ n-\mathrm{C}_{17}\left(\mathrm{Pr} / n-\mathrm{C}_{17}\right)$ versus phytane/ $n-\mathrm{C}_{18}\left(\mathrm{Ph} / n-\mathrm{C}_{18}\right)$ of the collected oils.

Plots of samples coming from Daqing oilfield show that the weathering modes of these samples are similar in different periods. All values of $\mathrm{Pr} / n-\mathrm{C}_{17}$ and $\mathrm{Ph} / n-\mathrm{C}_{18}$ of different samples, es- pecially the SL-1 sample, changed slightly during the weathered process. This consequently indicates that the cross plot of $\mathrm{Pr} / n$ $\mathrm{C}_{17}$ versus $\mathrm{Ph} / n-\mathrm{C}_{18}$ can be used to detect the source of spilled oils that maybe have passed a serious weathering process.

Based on the evaluation method of indices suggested by Stout et al. (2001) and Li et al. (2009), relative standard deviation (RSD, $\%$ ) is considered as an indicator to evaluate the variability of diagnostic indices in this experiment. The indices with RSD $<5 \%$ are probably not affected by weathering, while a RSD more than $5 \%$ suggests that weathering has a remarkable effect on the index.

The data in Table 3 and Fig. 3 demonstrate that no one ratio of common biomarker diagnostic parameters about $n$-alkanes in five samples displays obvious changes over weathering time, especially for $\mathrm{Pr} / \mathrm{Ph}$, LMW/HMW and WR in all five samples with a RSD of more than 5\%, indicating that these ratios are not valid for oil source identification of the spill moderately and severely degraded. In nine selected $n$-alkanes diagnosis ratio indicators, $\mathrm{OPE}_{1}, \mathrm{OPE}_{2}$ and CPI in sample DQ-67-75, DQ-1 and SL-1 maintained good stability in the 210-day weathering processes because their relative deviation (RSD) are less than $5 \%$. The results

Table 3. RSD of diagnostic ratios of different weathered oils

\begin{tabular}{|c|c|c|c|c|c|}
\hline & \multicolumn{5}{|c|}{ Sample No. } \\
\hline & DQ-67-75 & DQ-1 & LH-1 & LH-7-06 & SL-1 \\
\hline $\mathrm{Pr} / \mathrm{Ph}$ & 18.17 & 13.19 & 13.59 & 25.04 & 19.05 \\
\hline $\mathrm{Pr} / n-\mathrm{C}_{17}$ & 12.04 & 22.02 & 37.99 & 7.47 & 2.71 \\
\hline $\mathrm{Ph} / n-\mathrm{C}_{18}$ & 20.05 & 20.86 & 12.55 & 33.26 & 3.76 \\
\hline $\mathrm{OEP}_{1}$ & 3.40 & 1.81 & 19.94 & 21.41 & 2.32 \\
\hline $\mathrm{OEP}_{2}$ & 1.39 & 0.94 & 38.67 & 19.79 & 2.01 \\
\hline $\mathrm{L} / \mathrm{H}$ & 9.14 & 20.31 & 20.84 & 25.56 & 24.71 \\
\hline CPI & 2.09 & 1.40 & 18.51 & 2.32 & 0.43 \\
\hline $\mathrm{C}_{18} /\left(\mathrm{C}_{12}-\mathrm{C}_{35}\right)$ & 18.29 & 1.27 & 9.38 & 23.31 & 6.63 \\
\hline WR & 5.31 & 21.85 & 33.14 & 31.11 & 18.56 \\
\hline $\mathrm{Ts} / \mathrm{Tm}^{1)}$ & 6.10 & 2.06 & 2.84 & 4.09 & 6.62 \\
\hline $\mathrm{C}_{31}-\mathrm{A}^{2)}$ & 3.30 & 3.60 & 2.42 & 0.82 & 0.69 \\
\hline $\mathrm{GAM}^{3)}$ & 38.68 & 9.64 & 8.54 & 9.98 & 1.15 \\
\hline $\mathrm{C}_{29^{-}}-\mathrm{B}^{4)}$ & 2.04 & 1.51 & 3.36 & 3.61 & 2.25 \\
\hline $\mathrm{C}_{29}-\mathrm{C}^{5)}$ & 3.42 & 1.05 & 3.05 & 8.88 & 2.96 \\
\hline $\mathrm{C}_{27} / \mathrm{C}_{29}{ }^{6)}$ & 0.94 & 1.71 & 2.69 & 11.66 & 1.51 \\
\hline $\left.\mathrm{STE} / \mathrm{HOP}^{7}\right)$ & 7.37 & 5.73 & 17.86 & 2.49 & 5.52 \\
\hline
\end{tabular}

Notes: ${ }^{1)}$ Ratio of 18 $\alpha$-22, 29, 30-trisnorhopane relative to 17 $\alpha$-22, 29, 30-trisnorhopane; ${ }^{2} \mathrm{C}_{31} 22 \mathrm{~S}(22 \mathrm{~S}+22 \mathrm{R}): 22 \mathrm{~S}(22 \mathrm{~S}+22 \mathrm{R})$ for $\mathrm{C}_{31}{ }^{-17 \alpha}$, $21 \beta(\mathrm{H})$-homohopane; ${ }^{3)} \mathrm{Gammacerane} / \mathrm{C}_{30} \alpha \beta$ hopane; ${ }^{4)} \mathrm{C}_{29} 20 \mathrm{~S} /(20 \mathrm{~S}+20 \mathrm{R})$ : ratios of $20 \mathrm{~S} /(20 \mathrm{~S}+20 \mathrm{R})$ for $\mathrm{C}_{29}-5 \alpha(\mathrm{H}), 14 \alpha(\mathrm{H}), 17 \alpha(\mathrm{H})$-steranes; 5) $\mathrm{C}_{29} \beta \beta /(\beta \beta+\alpha \alpha): 5 \alpha(\mathrm{H}), 14 \beta(\mathrm{H}), 17 \beta(\mathrm{H}) /[5 \alpha(\mathrm{H}), 14 \beta(\mathrm{H}), 17 \beta(\mathrm{H})+5 \alpha(\mathrm{H}), 14 \alpha(\mathrm{H}), 17 \alpha(\mathrm{H})]$ for $\mathrm{C}_{29} ;{ }^{6} \mathrm{C}_{27} / \mathrm{C}_{29}: 5 \alpha(\mathrm{H}), 14 \alpha(\mathrm{H}), 17 \alpha(\mathrm{H})-20 \mathrm{R}-$ steranes; ${ }^{7)}$ Steranes/hopanes: $\mathrm{C}_{27}-\mathrm{C}_{28}-\mathrm{C}_{29}$ steranes $/ \mathrm{H}_{30}$. RSD represents relative standard deviation (\%).

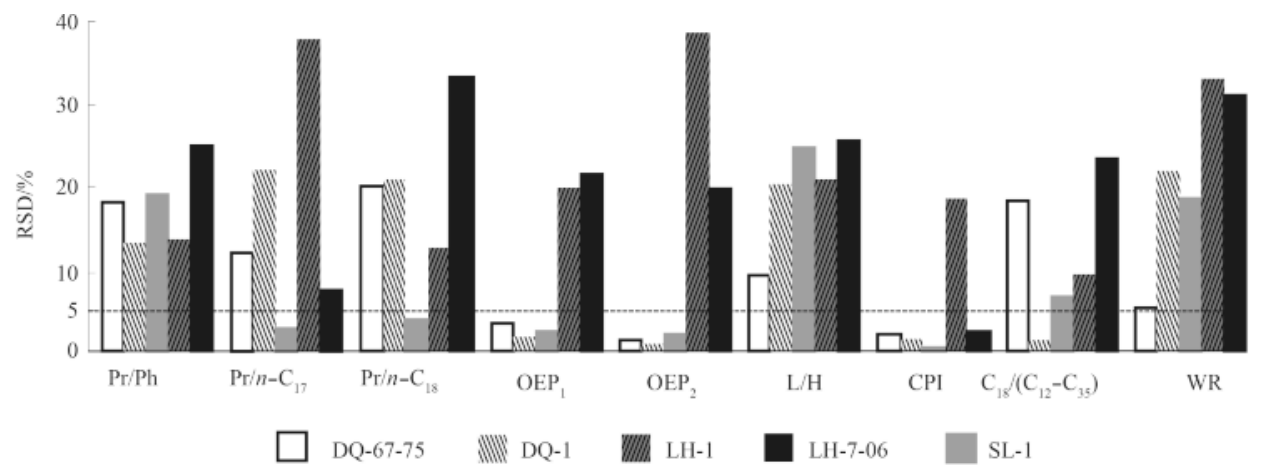

Fig. 3. RSD (\%) of some common biomarker diagnostic parameters of $n$-alkanes in oils. 
indicate some common biomarker diagnostic parameters in selected samples are useful in oil source identification.

\subsection{Variation of terpanes and steranes}

Compared to low-molecular weight biomarkers that are susceptible to weathering process, high-molecular weight biomarkers are relatively resistant to weathering and can be useful correlation tools for weathered oils. In general, terpane and sterane biomarkers as high molecular weight organic compounds are reported for having a much tiny water solubility and more resistant to degradation than $n$-alkanes and isoprenoids (Prince et al., 1994; Wang and Stout, 2007; Suneel et al., 2013; Bayona et al., 2015).

In this paper, the influence of the weathering process to seven diagnostic biomarker ratios related to terpane and sterane biomarkers that have been selected are discussed. These seven

Table 4. RSD of diagnostic ratios of different weathered oils

\begin{tabular}{|c|c|c|c|c|c|c|c|c|c|c|c|c|c|c|c|}
\hline & \multicolumn{15}{|c|}{ Sample No. } \\
\hline & \multicolumn{3}{|c|}{ DQ-67-75 } & \multicolumn{3}{|c|}{ DQ-1 } & \multicolumn{3}{|c|}{ LH-1 } & \multicolumn{3}{|c|}{ LH-7-06 } & \multicolumn{3}{|c|}{ SL-1 } \\
\hline & $0 \mathrm{~d}^{1)}$ & $30 \mathrm{~d}$ & $210 \mathrm{~d}$ & $0 \mathrm{~d}$ & $150 \mathrm{~d}$ & $210 \mathrm{~d}$ & $0 \mathrm{~d}$ & $150 \mathrm{~d}$ & $210 \mathrm{~d}$ & $0 \mathrm{~d}$ & $30 \mathrm{~d}$ & $210 \mathrm{~d}$ & $0 \mathrm{~d}$ & $150 \mathrm{~d}$ & $210 \mathrm{~d}$ \\
\hline $\mathrm{Ts} / \mathrm{Tm}$ & 0.89 & 0.97 & 1.01 & 1.44 & 1.50 & 1.46 & 1.05 & 1.11 & 1.10 & 1.31 & 1.24 & 1.37 & 0.43 & 0.49 & 0.45 \\
\hline $\mathrm{C}_{31}-\mathrm{A}$ & 0.46 & 0.44 & 0.45 & 0.57 & 0.60 & 0.56 & 0.58 & 0.59 & 0.56 & 0.59 & 0.58 & 0.57 & 0.56 & 0.56 & 0.55 \\
\hline GAM index & 0.20 & 0.26 & 0.41 & 0.21 & 0.17 & 0.19 & 0.05 & 0.06 & 0.06 & 0.22 & 0.30 & 0.23 & 0.22 & 0.22 & 0.22 \\
\hline $\mathrm{C}_{29}-\mathrm{B}$ & 0.48 & 0.49 & 0.50 & 0.46 & 0.46 & 0.47 & 0.45 & 0.48 & 0.47 & 0.41 & 0.41 & 0.44 & 0.35 & 0.34 & 0.35 \\
\hline $\mathrm{C}_{29}-\mathrm{C}$ & 0.45 & 0.46 & 0.43 & 0.43 & 0.43 & 0.42 & 0.40 & 0.40 & 0.42 & 0.44 & 0.43 & 0.43 & 0.40 & 0.43 & 0.41 \\
\hline $\mathrm{C}_{27} / \mathrm{C}_{29}$ & 0.61 & 0.61 & 0.62 & 0.61 & 0.62 & 0.60 & 0.75 & 0.78 & 0.79 & 0.95 & 0.90 & 0.88 & 0.78 & 0.79 & 0.81 \\
\hline STE/HOP & 0.17 & 0.15 & 0.15 & 0.17 & 0.16 & 0.15 & 0.11 & 0.11 & 0.15 & 0.23 & 0.26 & 0.24 & 0.40 & 0.40 & 0.44 \\
\hline
\end{tabular}

Notes: ${ }^{1)}$ Weathering time (d).

biomarker ratios as traditional maturity indicators, widely used in petroleum exploration, are showed in Table 4.

Just like $n$-alkanes, there are also significant differences in the distribution of these fractions, with respect to biomarker diagnostic parameters in the different initial oils and their weathered oils because of different oil sample coming from different oil source. This indicted that change modes of biomarker diagnostic parameters are not affected by oilfield types. The results (Table 4 and Fig. 4) show that almost all these seven biomarker diagnostic parameters of all five crude oil samples in the weathered oil did not change significantly and were similar to these parameters of the initial crude oils except Ts/Tm of some samples (DQ-67-75 and LH-7-06) and $\mathrm{C}_{27} / \mathrm{C}_{29}$ of LH-7-06. This indicts that terpanes and steranes retained their molecular compositions during moderate and heavy weathering process and these seven biomarker diagnostic parameters can be used in tracking the origin and sources of hydrocarbon pollution in the marine environment.
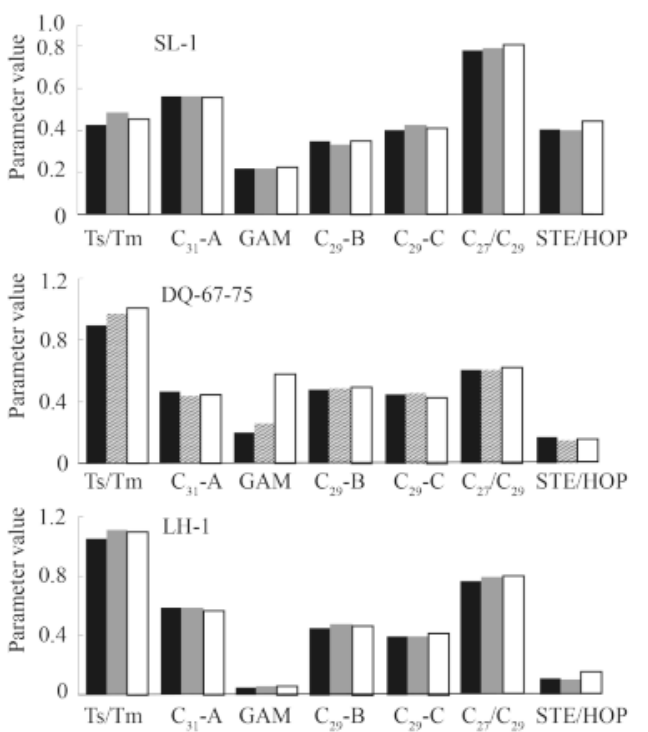

The data in Table 3 and Fig. 5 demonstrate that only two indices in seven diagnostic biomarker ratios $\left(\mathrm{C}_{31}-\mathrm{A}\right.$ and $\left.\mathrm{C}_{29}-\mathrm{B}\right)$ in all five samples have lower standard deviations (SDs) and RSD $(<5 \%)$, displaying obscure changes during weathering process. The results indicate that $\mathrm{C} 3017 \alpha, 21 \beta(\mathrm{H})$-hopane and its extended homologs (homohopanes) are not always stable in the environment and laboratory experiments. In contrast, the other diagnostic ratios did not maintain good stability in the 210-day weathering processes even they also remained constant because their RSD are higher than $5 \%$. Based on the data, it is suggested that the seven diagnostic biomarker ratios of triterpanes and steranes are believed that they are more useful in oil source identification due to they showed no change after weathering process, despite of extensive saturate hydrocarbon losses .

Using the $\mathrm{C}_{29}$-B versus $\mathrm{C}_{31}$-A plot (Fig. 6), we can approximately divide the five different samples into three parts, because biomarker ratios of DQ-1 and samples from Liaohe oilfield are close to each other. This means we cannot easily distinguish

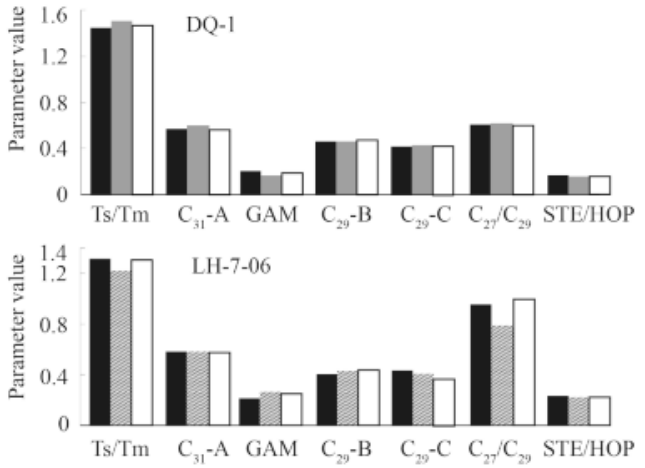

Fig. 4. Changes of ratios of terpanes and steranes in the weathering process. Refer to Table 3 for abbreviations. 


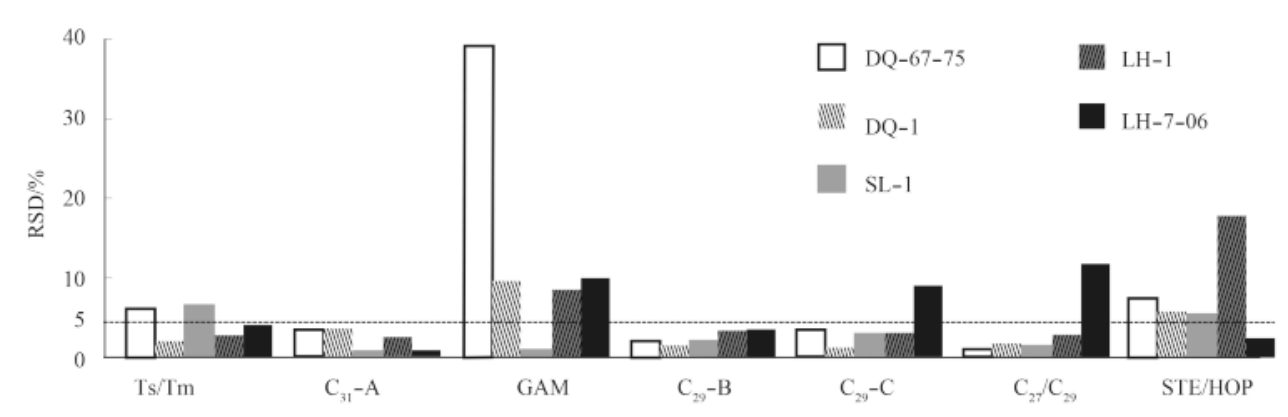

Fig. 5. RSD of some common biomarker diagnostic parameters of terpanes and steranes in weathered oils.

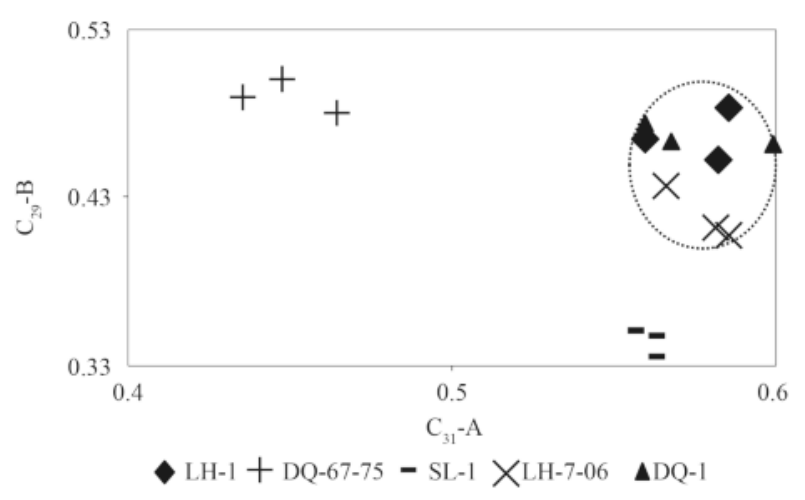

Fig. 6. $\mathrm{C}_{29}$-B versus $\mathrm{C}_{31}$-A for the collected oils from the five different oil fields.

these samples just using $\mathrm{C}_{29}-\mathrm{B}$ and $\mathrm{C}_{31}$-A as indicators, even though these two biomarker ratios are more useful in oil source identification than others.

\subsection{Variation of polycyclic aromatic hydrocarbons}

PAHs consist primarily of five families of compounds: naphthalenes, fluorenes, phenanthrenes, dibenzothiophenes, and chrysenes, each consisting of an un-substituted or parent compound and a series of alkylated compounds. The PAHs are relatively stable and diagnostic constituents of petroleum and provide more detailed compound-specific data that can be used to identify source (Douglas et al., 1996; Bari et al., 2014). Alkylated homologues of polycyclic aromatic hydrocarbons in crude oils can be used to confirm the source of oil pollutants, as well as access to ways and means of transport and transformation of pollutants information because they own qualities that $n$-alkanes always do not have, such as high stability and are much easier to be quantified than $n$-alkanes (Wang and Fingas,1995; Sun et al., 2009; Wang et al., 2009b; Zhao et al., 2008). The distribution characteristics of isomers with a single special sources and same methylation degree can determine spill sources because the speed of biodegradation are influenced by the aromatic isomerization position in the same family (Wang and Fingas, 2003; Yang et al., 2013). Generally, indicators in naphthalene and phenanthrene series (e.g., the methyl phenanthrene index (MPI), methyl phenanthrene ratio (MPR), and methylnaphthalene index (MNR)), as important maturity parameters, have been used in studies about the thermal maturity history of the source rock generating hydrocarbons (Salas et al., 2006; Sheppard et al., 2015), and are gradually applied to the identification of oil spills.

Figure 7 shows almost all polycyclic aromatic hydrocarbons indicators in sample DQ-67-75 except MPR and $\mathrm{MPDF}_{2}$ did not change significantly in various stages of weathering. MPR and $\mathrm{MPDF}_{2}$ indicators can also be used as indicators of moderate weathering process as those did not changed significantly in the 0-30 day weathering process; those two indicators are not suitable indexes in the 30-210 day weathering processes. Only $\mathrm{MPI}_{2}$ and Rc in these indicators maintained good stability in 210-day weathering processes and are more suitable for identifying oils which were moderately or severely weathered because their relative deviation (RSD) are lower than 5\% (Table 3).

In this paper, further repeatability of the developed method was assessed. From the standard deviation, the repeatability limit can be calculated which represents the maximum permitted difference between two repeated measurements. A reliable estimate of the standard deviation is required to calculate appropriate repeatability limits. The repeatability limit $(r)$ is reported as $r_{95 \%}=2.8 \times \bar{x} \times 5 \%=14 \% \bar{x}$, which gives the likely limits within which $95 \%$ of measurements should occur (Riley et al., 1980; Ramsey et al., 2014). In the present study, it can be considered that these two ratios are parallel ratios if the absolute difference between any two diagnostic ratios of oil fingerprinting is less than $r$. The evaluation results are "Y", meaning that these diagnostic ratios are fit for oil fingerprints identification, when the absolute difference between maxima and minima values of diagnostic is smaller than $r$. The evaluation results are "N", meaning these diagnostic ratios not suitable, when the absolute difference between Maxima and minima values is larger than repeatability.

In Table 5, the results of diagnostic ratios of seven commonly used biomarkers of polycyclic aromatic hydrocarbons are shown. Almost all absolute differences between any two diagnostic ra-

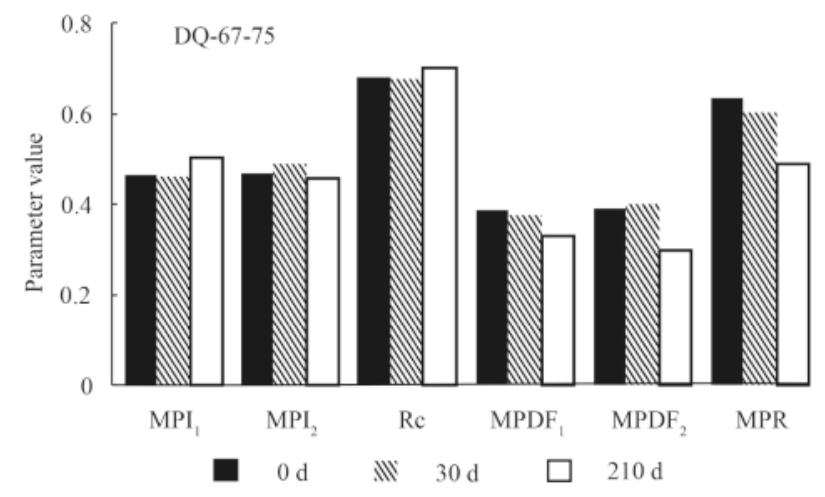

Fig. 7. Changes of ratios of polycyclic aromatic hydrocarbons in the weathering experiments. 
Table 5. RSD and changes of ratios of polycyclic aromatic hydrocarbons in oils (Sample DQ-67-75)

\begin{tabular}{|c|c|c|c|c|c|c|c|}
\hline & \multicolumn{3}{|c|}{ Weathering time/d } & \multirow{2}{*}{ RSD/\% } & \multirow{2}{*}{$\begin{array}{l}\text { Absolute } \\
\text { deviation }\end{array}$} & \multirow{2}{*}{$\begin{array}{l}\text { Repeatability } \\
\text { limit }\end{array}$} & \multirow{2}{*}{$\begin{array}{l}\text { The evaluation } \\
\text { results }\end{array}$} \\
\hline & 0 & 30 & 210 & & & & \\
\hline $\mathrm{MPI}_{1}{ }^{1)}$ & 0.46 & 0.46 & 0.50 & 5.12 & 0.02 & 0.07 & $\mathrm{Y}$ \\
\hline $\mathrm{MPI}_{2}{ }^{2)}$ & 0.47 & 0.49 & 0.46 & 3.48 & 0.01 & 0.07 & $\mathrm{Y}$ \\
\hline $\mathrm{Rc}^{3)}$ & 0.68 & 0.68 & 0.70 & 2.13 & 0.01 & 0.10 & $\mathrm{Y}$ \\
\hline $\mathrm{MPDF}_{1}^{4)}$ & 0.39 & 0.38 & 0.33 & 8.74 & 0.02 & 0.05 & $\mathrm{Y}$ \\
\hline $\mathrm{MPDF}_{2}{ }^{5)}$ & 0.39 & 0.40 & 0.30 & 15.73 & 0.04 & 0.05 & $\mathrm{Y}$ \\
\hline $\mathrm{MPR}^{6)}$ & 0.63 & 0.60 & 0.49 & 13.37 & 0.06 & 0.08 & $\mathrm{Y}$ \\
\hline
\end{tabular}

Notes: MP represents methylphenanthrene. ${ }^{1)} 1.5 \times(3-\mathrm{MP}+2-\mathrm{MP}) /(\mathrm{P}+9-\mathrm{MP}+1-\mathrm{MP}) ;{ }^{2)} 3 \times 2-\mathrm{MP} /(1-\mathrm{MP}+9-\mathrm{MP}) ;{ }^{3)} 0.6 \mathrm{MPI}{ }_{1}+0.40 ;{ }^{4)}(3-\mathrm{MP}+2-$ $\left.\mathrm{MP}) /(3-\mathrm{MP}+2-\mathrm{MP}+9-\mathrm{MP}+1-\mathrm{MP}) ;{ }^{5}\right) 2 \times 2-\mathrm{MP} /(3-\mathrm{MP}+2-\mathrm{MP}+9-\mathrm{MP}+1-\mathrm{MP}) ;{ }^{6}$ ) $2-\mathrm{MP} / 1-\mathrm{MP}$.

tios are less than $r$. This demonstrates that these diagnostic ratios are fit for oil fingerprints identification, and moreover, it can be able to determine that the two oil samples are from the same oil source.

\section{Conclusions}

No matter which diagnostic ratios used, it is apparent that there are significant differences in the distribution of these fractions in the different initial oils and their weathered oils. The above discussion also reveals that: the diagnostic ratios of $n$-alkanes (e.g., CPI, $\mathrm{Pr} / \mathrm{Ph}, \mathrm{Pr} / n$-C17, $\mathrm{Ph} / n$-C18 and LMW/HMW) are not valid for long term weathered oil source identification. Even those ratios declined slowly during 30 weathering days and could be used as diagnostic ratios for oil spill identification after short-term weathering process. In contrast, terpanes, steranes and PAHs retained their molecular compositions after moderate to severe degradation and almost all diagnostic ratios of them could be efficiently used in oil spill identification except Ts/Tm and C27/C29 in some samples, also MPR and MPDF2 in Sample DQ-67-75. In those efficient diagnostic ratios, only $\mathrm{C}_{31}-\mathrm{A}$ and $\mathrm{C}_{29}{ }^{-}$ $B$ in all five samples and MPI2 and Rc in Sample DQ-67-75 maintained good stability in the 210-day weathering processes and are more suitable for identifying moderate to severe weathered oils because their relative deviation (RSD) are lower than $5 \%$.

\section{Acknowledgements}

The authors thank Zhou Tao for his technical assistance in the GC-MS measurements carried out in the First Institute of Oceanography, State Oceanic Administration.

\section{References}

Adhikari P L, Maiti K, Overton E B. 2015. Vertical fluxes of polycyclic aromatic hydrocarbons in the northern Gulf of Mexico. Marine Chemistry, 168: 60-68

Bao Mutai, Wang Lina, Sun Peiyan, et al. 2012. Biodegradation of crude oil using an efficient microbial consortium in a simulated marine environment. Marine Pollution Bulletin, 64(6): 1177-1185

Bari M A, Kindzierski W B, Cho S. 2014. A wintertime investigation of atmospheric deposition of metals and polycyclic aromatic hydrocarbons in the Athabasca Oil Sands Region, Canada. Science of the Total Environment, 485-486: 180-192

Bayona J M, Domínguez C, Albaigés J. 2015. Analytical developments for oil spill fingerprinting. Trends in Environmental Analytical Chemistry, 5: 26-34

Burgherr P. 2007. In-depth analysis of accidental oil spills from tankers in the context of global spill trends from all sources. Journal of Hazardous Materials, 140(1-2): 245-256

D'Auria M, Emanuele L, Racioppi R, et al. 2009. Photochemical degradation of crude oil: Comparison between direct irradiation, photocatalysis, and photocatalysis on zeolite. Journal of Hazardous Materials, 164(1): 32-38

Di Gregorio S, Gentini A, Siracusa G, et al. 2014. Phytomediated bios- timulation of the autochthonous bacterial community for the acceleration of the depletion of polycyclic aromatic hydrocarbons in contaminated sediments. BioMed Research International, 2014: 891630

Douglas G S, Bence A E, Prince R C, et al. 1996. Environmental stability of selected petroleum hydrocarbon source and weathering ratios. Environmental Science \& Technology, 30(7): 2332-2339

Duan Yi, Wang Chuanyuan, Zheng Chaoyang, et al. 2008. Geochemical study of crude oils from the Xifeng oilfield of the Ordos basin, China. Journal of Asian Earth Sciences, 31(4-6): 341-356

Formolo M, Martini A, Petsch S. 2008. Biodegradation of sedimentary organic matter associated with coalbed methane in the Powder River and San Juan Basins, U.S.A. International Journal of Coal Geology, 76(1-2): 86-97

Frynas J G. 2012. Corporate social responsibility or government regulation?. Evidence on oil spill prevention. Ecology and Society, 17(4): 256-268

George S C, Volk H, Dutkiewicz A, et al. 2008. Preservation of hydrocarbons and biomarkers in oil trapped inside fluid inclusions for $>2$ billion years. Geochimica et Cosmochimica Acta, 72(3): 844-870

Hanson A D, Zhang S C, Moldowan J M, et al. 2000. Molecular organic geochemistry of the Tarim basin, Northwest China. American Association of Petroleum Geologists Bulletin, 84(8): 1109-1128

King G M, Kostka J E, Hazen T C, et al. 2015. Microbial Responses to the Deepwater horizon oil spill: from coastal wetlands to the deep sea. Annual Review of Marine Science, 7(1): 377-401

Kingston P F. 2002. Long-term environmental impact of oil spills. Spill Science \& Technology Bulletin, 7(1-2): 53-61

Kvenvolden K A, Hostettler F D, Carlson R R, et al. 1995. Ubiquitous tar balls with a California-source signature on the shorelines of Prince William Sound, Alaska. Environmental Science \& Technology, 29(10): 2684-2694

Lemkau K L, Peacock E E, Nelson R K, et al. 2010. The M/V Cosco Busan spill: Source identification and short-term fate. Marine Pollution Bulletin, 60(11): 2123-2129

Li Yun, Xiong Yongqiang, Yang Wanying, et al. 2009. Compound-specific stable carbon isotopic composition of petroleum hydrocarbons as a tool for tracing the source of oil spills. Marine Pollution Bulletin, 58(1): 114-117

Liu Xing, Wang Zhen, Ma Xindong, et al. 2009. Principal component analysis and distribution of paraffinic hydrocarbons in crude oils produced in Asia and Africa. Environmental Pollution \& Control (in Chinese), 31(8): 41-45

Liu Dan, Zhu Ling. 2014. Assessing China's legislation on compensation for marine ecological damage: A case study of the Bohai oil spill. Marine Policy, 50: 18-26

Mello P A, Pereira J S F, Mesko M F, et al. 2012. Sample preparation methods for subsequent determination of metals and nonmetals in crude oil-A review. Analytica Chimica Acta, 746: $15-36$

Middaugh D P, Chapman P J, Shelton M E. 1996. Responses of embryonic and larval inland silversides, Menidia beryllina, to a water-soluble fraction formed during biodegradation of artificially weathered Alaska North Slope crude oil. Archives of Environmental Contamination and Toxicology, 31(3): 410-419

Peters K E, Fraser T H, Amris W, et al. 1999. Geochemistry of crude oils from eastern Indonesia. American Association of Petro- 
leum Geologists Bulletin, 83(12): 1927-1942

Peters K E, Scheuerman G L, Lee C Y, et al. 1992. Effects of refinery processes on biological markers. Energy \& Fuels, 6(5): 560-577

Peters K E, Walters C C, Moldowan J M. 2005. The Biomarker Guide, Volume 1: Biomarkers and Isotopes in the Environment and Human History. Cambridge: Cambridge University Press, 1-490

Prince R C, Elmendorf D L, Lute J R, et al. 1994. 17.alpha.(H)21.beta.(H)-hopane as a conserved internal marker for estimating the biodegradation of crude oil. Environmental Science \& Technology, 28(1): 142-145

Radović J R, Aeppli C, Nelson R K, et al. 2014. Assessment of photochemical processes in marine oil spill fingerprinting. Marine Pollution Bulletin, 79(1-2): 268-277

Ramsey III E, Meyer B M, Rangoonwala A, et al. 2014. Oil source-fingerprinting in support of polarimetric radar mapping of $\mathrm{Ma}$ condo-252 oil in Gulf Coast marshes. Marine Pollution Bulletin, 89(1-2): 85-95

Riley R G, Thomas B L, Anderson J W, et al. 1980. Changes in the volatile hydrocarbon content of Prudhoe Bay Crude Oil treated under different simulated weathering conditions. Marine Environmental Research, 4(2): 109-119

Samuels W B, Amstutz, D E, Bahadur R, et al. 2013. Development of a global oil spill modeling system. Earth Science Research, 2(2): $52-61$

Salas N, Ortiz L, Gilcoto M, et al. 2006. Fingerprinting petroleum hydrocarbons in plankton and surface sediments during the spring and early summer blooms in the Galician coast (NW Spain) after the Prestige oil spill. Marine Environmental Research, 62(5): 388-413

Sheppard R E, Polissar P J, Savage H M. 2015. Organic thermal maturity as a proxy for frictional fault heating: Experimental constraints on methylphenanthrene kinetics at earthquake timescales. Geochimica et Cosmochimica Acta, 151: 103-116

Stout S A, Uhler A D, McCarthy K J. 2001. A strategy and methodology for defensibly correlating spilled oil to source candidates. Environmental Forensics, 2(1): 87-98

Sun Peiyan, Cao Lixin, Li Mei, et al. 2009. Studies on effects of Bohai crude oil fingerprint in simulantion evaporation weathering in laboratory. Marine Sciences (in Chinese), 33(2): 22-26

Suneel V, Vethamony P, Zakaria M P, et al. 2013. Identification of sources of tar balls deposited along the Goa coast, India, using fingerprinting techniques. Marine Pollution Bulletin, 70(1-2): 81-89

Teich J L, Pemberton M R. 2015. Epidemiologic studies of behavioral health following the Deepwater horizon oil spill: limited impact or limited ability to measure?. The Journal of Behavioral Health Services \& Research, 42(1): 77-85
Wang Chuanyuan, Chen Bing, Zhang Baiyu, et al. 2013. Fingerprint and weathering characteristics of crude oils after Dalian oil spill, China. Marine Pollution Bulletin, 71(1-2): 64-68

Wang Zhendi, Fingas M. 1995. Differentiation of the source of spilled oil and monitoring of the oil weathering process using gas chromatography-mass spectrometry. Journal of Chromatography A, 712(2): 321-343

Wang Zhendi, Fingas M. 2003. Development of oil hydrocarbon fingerprinting and identification techniques. Marine Pollution Bulletin, 47(9-12): 423-452

Wang Zhendi, Fingas M, Landriault M, et al. 1997. Using systematic and comparative analytical data to identify the source of an unknown oil on contaminated birds. Journal of Chromatography A, 775(1-2): 251-265

Wang Zhendi, Fingas M, Page D S. 1999. Oil spill identification. Journal of Chromatography A, 843(1-2): 369-411

Wang Zhendi, Fingas M, Sergy G. 1994. Study of 22-year-old Arrow oil samples using biomarker compounds by GC/MS. Environmental Science \& Technology, 28(9): 1733-1746

Wang Zhendi, Fingas M, Sergy G. 1995. Chemical characterization of crude oil residues from an arctic beach by GC/MS and GC/FID. Environmental Science \& Technology, 29(10): 2622-2631

Wang Chuanyuan, He Shijie, Li Yantai, et al. 2009a. Study on the state and ecological effect of spilled oil pollution in Chinese coastal waters. Marine Sciences (in Chinese), 33(6): 57-60

Wang Chuanyan, He Shijie, Wang Min, et al. 2009b. Identification of weathered crude oils by aromatioc hydrocarbon fingerprinting. Environmental Chemistry (in Chinese), 28(3): 427-431

Wang Zhendi, Stout S A. 2007. Oil Spill Environmental Forensics: Fingerprinting and Source Identification. Boston: Academic Press, $1-45$

Wang Zhendi, Stout S A, Fingas M. 2006. Forensic fingerprinting of biomarkers for oil spill characterization and source identification. Environmental Forensics, 7(2): 105-146

Woolgar L. 2008. Assessing the increasing risk of marine oil pollution spills in China. In: Proceedings of International Oil Spill Conference. Savannah, GA, USA: American Petroleum Institute, 711-715

Yang Chun, Wang Zhendi, Liu Yingrong, et al. 2013. Aromatic steroids in crude oils and petroleum products and their applications in forensic oil spill identification. Environmental Forensics, 14(4): 278-293

Zhao Yuhui, Sun Peiyan, Wang Xinping, et al. 2008. Identification of crude oils in Bohai Sea by polycyclic aromatic hydrocarbon fingerprinting. Chinese Journal of Chromatography (in Chinese), 26(1): 43-49 